\title{
A Study of Heavy Metals in the Dust Fall around Assiut Fertilizer Plant
}

\author{
Thabet A. Mohamed ${ }^{1}$, Mohamed Abuel-Kassem Mohamed ${ }^{2}$, Ragab Rabeiy ${ }^{2}$, Mahmoud A. Ghandour ${ }^{3}$ \\ ${ }^{1}$ National Institute of Occupational Safety and Health (NIOSH), Assiut, Egypt; ${ }^{2}$ Mining and Metallurgical Engineering Department, \\ Faculty of Engineering, Assiut University, Assiut, Egypt; ${ }^{3}$ Chemistry Department, Faculty of Science, Assiut University, Assiut, Egypt. \\ Email: mfye64@gmail.com
}

Received June $19^{\text {th }}, 2013$; revised July $23^{\text {rd }}, 2013$; accepted August $21^{\text {st }}, 2013$

Copyright (C) 2013 Thabet A. Mohamed et al. This is an open access article distributed under the Creative Commons Attribution License, which permits unrestricted use, distribution, and reproduction in any medium, provided the original work is properly cited. In accordance of the Creative Commons Attribution License all Copyrights (C) 2013 are reserved for SCIRP and the owner of the intellectual property Thabet A. Mohamed et al. All Copyright (C) 2013 are guarded by law and by SCIRP as a guardian.

\begin{abstract}
A study of an environmental assessment of dust fall and the associated heavy metal contents was conducted during the period from the first of March 2011 to the end of February 2012 at adjoining area of a phosphate fertilizer plant. Around the industrial area 8 dust fall stations were established and one of them was built upwind far from pollution activities to be taken as a control sample. Dust fall samples collected monthly weighed and then prepared to be analyzed through Inductively Coupled Plasma-Mass Spectroscopy (ICP-MS) to obtain heavy metal concentration. Meteorological parameters influencing the distribution of dust fall such as wind speed and direction, temperature, humidity, rain fall and pressure were determined. Results showed that deposition flow rates were 38.2. 47.5, 57.7, 44.3, 39.4, 38.2, 42.7 and $5.9 \mathrm{~g} / \mathrm{m}^{2} \cdot$ month for the sites No., $1,2,3,4,5,6,7$ and 8 respectively, and were compared with the findings of other investigators of like industrial areas worldwide. Levels of heavy metal $\mathrm{As}, \mathrm{Cu}, \mathrm{Pb}, \mathrm{Zn}, \mathrm{Cd}$, and $\mathrm{Hg}$ in the deposited dust fall were $3.30,26.46,22.33,235.00,4.53$ and $3.80 \mu \mathrm{g} / \mathrm{g}$ respectively. Enrichment coefficients of the heavy metals in the dust fall were found to be significant and reached the values $1.81,0.90,0.85,0.65,0.41$ and 0.35 for zinc, lead, cadmium, copper, mercury and arsenic respectively. The paper ends with results and recommendations suggesting a methodology to remediate the investigated area polluted with heavy metals and control measures for the fertilizer plant to reduce pollution into the surrounding environment.
\end{abstract}

Keywords: Heavy Metal; Dust Fall Station; Deposition Flow Rate; Phosphate Fertilizer Plant; Meteorological Parameters

\section{Introduction}

The anthropogenic impact on the adjoining environments of industrial complexes has been documented in many parts of the world [1-3]. Heavy metals such as $\mathrm{As}, \mathrm{Cu}, \mathrm{Pb}$, $\mathrm{Z}, \mathrm{Cd}$ and $\mathrm{Hg}$ have been evaluated in an agricultural area nearby the phosphate fertilizer plant, Assiut, Egypt. Heavy metals resulted from industrial activities are considered seriously if they exist in the environment with excess concentration than background values. A large number of studies have been conducted in urban and rural environments and reported that particulate matter surface has a greater tendency of binding up soil derived elements and larger surface area of small particle size has affinity of higher accumulation of elemental concentration $[4,5]$.
Dust fall is depleted continuously from the atmosphere through two major routes: dry and/or wet deposition. The influencing factors of dust fall path depend upon meteorological conditions such as the intensity and distribution of rain fall, wind direction and velocity, humidity, temperature and pressure [6,7]. Heavy metal pollution of the atmosphere can be estimated by determining the concentration of these heavy metals in settleable particles, because the heavy metals are associated with the solid particulate matter in many forms. Lead is one of the metals of most interest in environmental samples. In their studies, many investigators have concentrated on the determination of lead alone in particulate matter [8,9] but other heavy metals have also been extensively studied [10-13]. 
Eight dust fall stations were distributed downwind the phosphate fertilizer plant to determine heavy metal concentration in atmospheric deposition where station No. 8 was placed upwind in unpolluted area to be taken as a control sample [14]. Dust fall samples were collected monthly and analyzed using Inductively Coupled Plasma-Microscopy (ICP-MS). Concentrations of heavy metals $(\mu \mathrm{g} / \mathrm{g})$ collected from dust fall stations were obtained as well as dust fall rates $\left(\mu \mathrm{g} \cdot \mathrm{m}^{-2} \cdot \mathrm{mon}^{-1}\right)$ and their related statistical data and were compared with other results reported in the literature. Obtained reports of dust fall measurements showed that the area was enriched with heavy metals and their concentrations were above the threshold limit values stated by the environment law 4/1994.

The aim of this study was to estimate dust fall released in the vicinity of the phosphate fertilizer plant and determination of heavy metal concentrations associated with these dusts. These dusts furnished with heavy metals are deposited in soil raising its mineralogical composition and give rise to soil pollution. In fact, this is the first data published in terms of freely available literature on the levels of heavy metals in the atmosphere since the establishment of the phosphate fertilizer plant in 1978.

\section{Materials and Methods}

\subsection{Study Area}

The study was conducted during 2010-2011 around Manqabad phosphate fertilizer factory $\left(27^{\circ} 11^{\prime} 47^{\prime \prime} \mathrm{N}\right.$, $31^{\circ} 6^{\prime} 59$ "E) situated at $9 \mathrm{~km}$ north of city of Assiut, Egypt. The phosphate factory of Assiut, established in 1978 with an installed capacity of $14,600 \mathrm{mt}$, to reach the total plant capacity of $205,000 \mathrm{mt} / \mathrm{year}$. The plant is located between the western bank of the River Nile and El-Ibraheimia navigation canal and joined with the main Express roads of Assiut-Cairo, Assiut-Aswan and the Railway station. The climate of the area ranges from tropical to mild where the year is divisible into a hot and dry summer season (May-August) and a cold winter season (November-February). October and March are transition months. Mean monthly maximum temperature ranges between $20.3^{\circ} \mathrm{C}$ in January and $45^{\circ} \mathrm{C}$ June and mean minimum temperature between $15^{\circ} \mathrm{C}$ in January and 30 ${ }^{\circ} \mathrm{C}$ in May. Mean annual rain fall is $180 \mathrm{~mm}$, about $90 \%$ of which occurs during winter season. During the study period however, the annual rain fall remained below this level. Wind directions shifts from predominantly northwesterly during November through March and north-westerly to northerly for most of the remaining months.

The soil of the area is alfisols from parent materials medium in limestone and soil texture ranges from sand to loamy sand. The area under investigation is an agricultural of 400 feddans, lived by about 6000 individuals inhabiting in different communities. The original vegetation comprises of wheat, faba bean, and clover in winter and in summer plants are sorghum, maize and cotton. In addition, some fruit orchards like grapes, banana, jawava and figs. Figure 1 shows the composition of the area related to the location of the fertilizer plant.

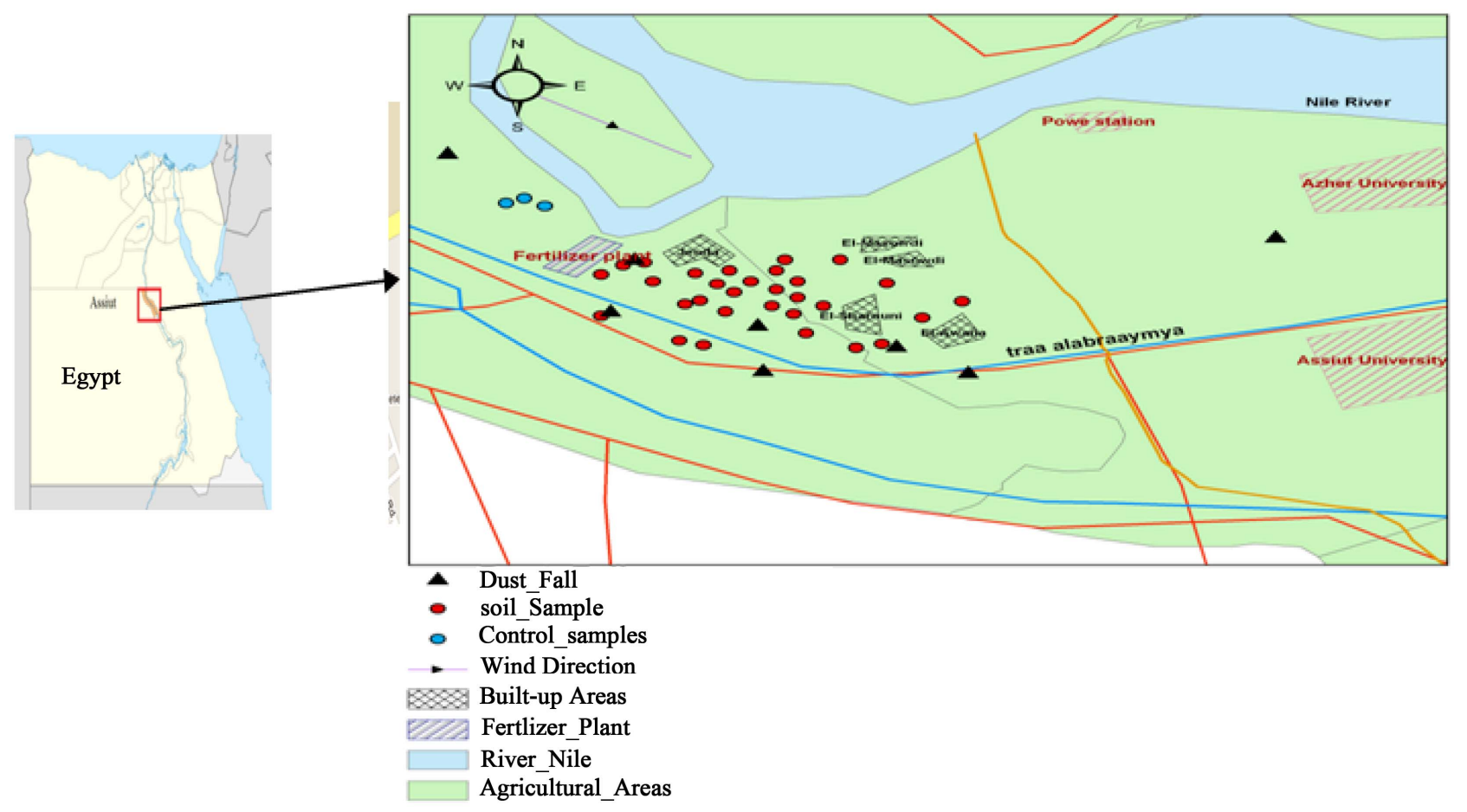

Figure 1. A map showing the fertilizer plant and related samples. 


\subsection{Dust Fall Stations}

First of all, studies that conducted in evaluating dust fall around surrounding areas of industrial complexes were studied [15-21]. Then based on recommendation of the American Society for Testing and Materials Standard Method for collection of dust fall ASTM Method D-1739 and analysis books, 8 home dust fall stations were designed and selected as shown in Figure 2. The following criteria were used to select the stations. The distance between stations $3 \mathrm{~km}$ and sampling must be done in an open area, far from tall buildings, the distance from buildings should be at least $20 \mathrm{~m}$, stations should be away from local sources of pollution, easily accessible and away from being damaged (Fang, et al., 2004). Collection of dust fall was accomplished using a home dust fall station as shown in Figure 3. The collector is consisted of a glass box $30 \times 30 \times 30 \mathrm{~cm}$ fixed on a vertical stand of about $2 \mathrm{~m}$ to prevent terrestrial dust to pollute the sample. The sample was collected in Petri deposition dish placed above a meter balance interior the glass box which may give the weight of dust fall directly at any time. Also the station is provided with an electric circuit giving alarm to prevent bird's droppings. The station is provided with a shield to prevent wind fluctuations. Petri dishes are replaced at the end of each month to collect dust fall samples.

Meteorological records indicated that north-west direction is prevailing wind direction hence, it was taken as downwind direction for the present study. The device of Global Positioning Systems GPS (Garmen 62s) was used to demonstrate the locations of dust fall stations. Table 1 gives the global position coordinates of distributed dust fall stations in the area nearby the fertilizer plant.

\subsection{Sample Collection and Preparation}

Dust fall stations were mounted $1.5 \mathrm{~m}$ high tripods to

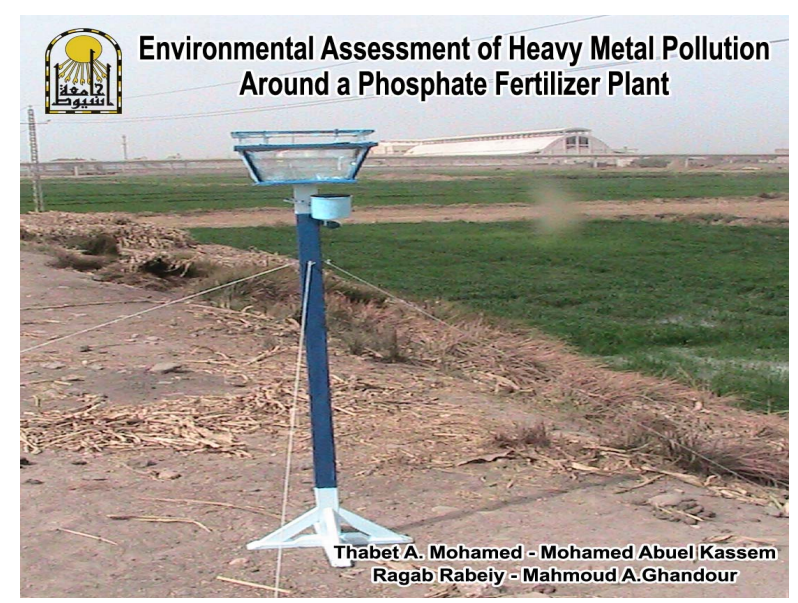

Figure 2. Dust fall station in the area near the phosphate fertilizer plant.
Table 1. Location of dust fall stations and co-ordinates.

\begin{tabular}{ccc}
\hline Station & N & E \\
\cline { 2 - 3 } 1 & 271148 & 3197 \\
2 & 27119 & 31813 \\
3 & 271117 & 31741 \\
4 & 271138 & 31713 \\
5 & 271122 & 3176 \\
6 & 27111 & 31743 \\
7 & 271058 & 31830 \\
8 & 271234 & 31648 \\
\hline
\end{tabular}

avoid the collection of dust picked up by wind eddies. There was a bird ring on each holder to avoid material from birds. The collectors were exposed to the atmosphere for a sampling period of 30 days. It should be noted that the measurements represent dry deposition only, as there were no rainfall during the sampling period.

The dry deposits (settleable particulates) were transferred from the collectors and placed in an iced container and transported to the analysis laboratory. The content of dust fall was dried at $105^{\circ} \mathrm{C}$ to a constant mass, and then it was weighed and the quantity of dust fall was computed in $\mu \mathrm{g} / \mathrm{m}^{2}$ month. About $0.10 \mathrm{~g}$ of the dried samples was accurately weighed and extracted with concentrated ultra-pure nitric acid, sonicated for $30 \mathrm{~min}$ in a test tube heater for one hour, left overnight, and then the solutions were filtered and diluted with $1 \% \mathrm{HNO}_{3}$ in $25 \mathrm{ml}$ polyethylene volumetric flask to the mark [23] $\mathrm{As}, \mathrm{Cu}, \mathrm{Pb}, \mathrm{Zn}$, $\mathrm{Cd}$ and $\mathrm{Hg}$ in the dustfall were analytically determined using Inductively Coupled Plasma-Mass Spectroscopy (ICP-MS-Perkin Elmer).

\section{Results and Discussion}

\subsection{Determination of Dust Fall}

The annual mean rates of deposited dust collected in an agricultural area from March 2011 to the end of February 2012 around the phosphate fertilizer plant have the values of 38.2. 47.5, 57.7, 44.3, 39.4, 38.2, 42.7 and 5.9 $\mathrm{g} / \mathrm{m}^{2}$ month for the sites no. $1,2,3,4,5,6,7$ and 8 respectively. Sites no 1, 2, 3 are located down wind of the factory, so they received higher deposition rates of particulate than that of other sites and this is due to the impact of the fertilizer plant on the surrounding area. Fugitive dust and stack emissions especially during charging and discharging of rock mills are the main sources of particulate emissions. This rate of deposition is considered very heavy compared to Pennsylvania guidelines for dust fall [24], moreover, these rates of deposition exceed in terrible amount of standards for dust 




\section{sketch of dust fall station}

ELECTRIC CIRCUIT

BELL

KEY

GLASS BOX

SHIELD OF WIND

OPENING

PETRI DISH

BALANCE METER

TRIPOD (HEIGHT $=3 \mathrm{~m})$

Figure 3. Sketch showing the compartments of the dust fall station [22].

deposits in many countries, for instance, the air quality standards in USA is $5.7 \mathrm{~g} / \mathrm{m}^{2} \cdot$ month and is $1.93 \mathrm{~g} / \mathrm{m}^{2}$. month as a background value (Stern, 1986), while it is 14 $\mathrm{g} / \mathrm{m}^{2} \cdot$ month for industrial areas according to Egyptian law 470/1970. The Environmental Information and Monitoring Program of Egypt (EIMP) reported that, reports from developed countries referred that if dust fall values are less than $10 \mathrm{~g} / \mathrm{m}^{2} \cdot$ month, the area may be considered clean. According to [25] SANs (2005) the new dust fall standard has been established and widely used to determine the potential of dust fall in residential and industrial areas. Sans (2005) standard threshold stated that deposited dust in industrial area lies between 18 and 36 $\mathrm{g} / \mathrm{m}^{2} \cdot$ month as it shown in Table 2 .

Sites no 2, 3 showed the vigorous increase of dust fall than other sites and exceeding other sites the alert limit to take action of $72 \mathrm{~g} / \mathrm{m}^{2} \cdot$ month to immediate action and remediation required following the first incidence of dust fall rate being exceeded. Dust fall deposition in Site No. 4 is affected by the emissions of the power plant which present to the north east of this site, so the dust fall rate of this site is influenced by the emissions of the fertilizer factory and the power plant emissions. Site 5 is affected by the emissions of the fertilizer plant and vehicular emissions of the high way linking Assiut-Cairo. Site 8 is a reference where deposition rate is $5.9 \mathrm{~g} / \mathrm{m} \cdot \mathrm{month}$ and it located upwind and far from pollution. In Sites 2, 3 rate depositions are 6 times and 7 times to that of the back- ground site. But rates sites 4, 5, 6, 7 equals 4 times approximately that of the reference site. This gives evidence that the industrial mechanical operations and chemical processes take part in the factory is responsible for the increased rates of dust fall in the adjacent area.

\subsection{Heavy Metal Contest in Dust Fall}

Heavy metal concentration are represented in dust fall are given in Table 3 and their related statistical data is illustrated in Table 4. It is revealed that there is variation of heavy metal concentration in dust fall collected from different dust fall stations. The highest concentration value of $\mathrm{Cd}$ reached $11.65 \mathrm{mg} / \mathrm{kg}$ in site No. 7 affected by pollution sources of fertilizer emissions beside vehicular emission from high Express way and railway. The annual deposition of $\mathrm{Cd}$ is $4.53 \mu \mathrm{g} / \mathrm{g}$ and the higher value of $\mathrm{Pb}$ is $51.71 \mu \mathrm{g} / \mathrm{g}$ mainly affected from phosphate fertilizer manufacturing.

The annual mean value of $\mathrm{Pb}$ is $22.33 \mu \mathrm{g} / \mathrm{g}$ that exceeds much the control value of Site 8 that equals 5.33 $\mu \mathrm{g} / \mathrm{g}$. As for $\mathrm{Cu}$ and $\mathrm{Zn}$ the maximum values were 46.25 , $522.9 \mu \mathrm{g} / \mathrm{g}$ and minimum values are $13.27,105.8 \mu \mathrm{g} / \mathrm{g}$ and the mean values are $29.46,235 \mu \mathrm{g} / \mathrm{g}$ respectively, and this exceed much the control values of $\mathrm{Pb}$ and $\mathrm{Zn}$ in site 8 . For $\mathrm{Hg}$ and $\mathrm{As}$, the range is about 0.23 to 3.98 $\mu \mathrm{g} / \mathrm{g}$, and 0.41 to $3.46 \mu \mathrm{g} / \mathrm{g}$ for $\mathrm{Hg}$ and As respectively. The maximum values of $\mathrm{Hg}$ and As were 7.06 and 4.88 $\mu \mathrm{g} / \mathrm{g}$ respectively, where the minimum values $0.25,0.4$ 
Table 2. Threshold limit values of dust fall [24].

\begin{tabular}{cccc}
\hline Band No. & Label & Dust fall rate $\mathrm{D} \mathrm{g} / \mathrm{m}^{2} \cdot \mathrm{month}$ & Action taken \\
\hline 1 & Residential & $\mathrm{D}<18$ & Permissible for residential and light commercial \\
2 & Industrial & $24<\mathrm{D}<36$ & $\begin{array}{r}\text { Permissible for heavy commercial and industrial } \\
\text { Action }\end{array}$ \\
4 & Alert & $36<\mathrm{D}<72$ & $\begin{array}{r}\text { Requires investigation and remediation if two sequential months lie in } \\
\text { this band or more than three occur in a year }\end{array}$ \\
Immediate action and remediation required following the first incidence of dust \\
fall rate being exceeded, incident report to be submitted to relevant authority.
\end{tabular}

Table 3. Represents concentrations of heavy metals $(\mu \mathrm{g} / \mathrm{g})$ in dust fall.

\begin{tabular}{cccccccc}
\hline St. No. & $\mathrm{Cd}$ & $\mathrm{Pb}$ & $\mathrm{Cu}$ & $\mathrm{Zn}$ & $\mathrm{Hg}$ & $\mathrm{As}$ \\
\hline 1 & 2.25 & 12.15 & 30.72 & 209.39 & 0.38 & 0.41 \\
2 & 6.68 & 3.16 & 16.23 & 133.43 & 3.05 & 3.84 \\
3 & 3.83 & 51.72 & 26.09 & 175.95 & 2.52 & 4.88 \\
4 & 4.55 & 24.20 & 37.33 & 312.00 & 2.37 & 1.58 \\
5 & 5.08 & 38.82 & 46.75 & 105.08 & 0.23 & 3.42 \\
6 & 2.13 & 11.02 & 13.27 & 399.30 & 7.06 & 0.53 \\
Control ST 8 & 11.56 & 33.50 & 29.57 & 522.60 & 8.98 & & 8.46 \\
Annual Average & 4.53 & 5.22 & 8.33 & 27.15 & 235.00 & 3.80 & 1.75 \\
\hline
\end{tabular}

Table 4. Represents the statistical data of heavy metals in dust fall samples.

\begin{tabular}{|c|c|c|c|c|c|c|}
\hline St. No. & $\mathrm{Cd}$ & $\mathrm{Pb}$ & $\mathrm{Cu}$ & $\mathrm{Zn}$ & $\mathrm{Hg}$ & As \\
\hline Mean & 4.53 & 22.33 & 29.46 & 235.00 & 3.80 & 3.30 \\
\hline Max & 11.65 & 51.72 & 46.75 & 522.90 & 8.98 & 8.46 \\
\hline Min & 2.12 & 3.16 & 13.27 & 105.80 & 0.23 & 0.24 \\
\hline SD & 3.26 & 17.57 & 11.58 & 152.98 & 3.31 & 2.84 \\
\hline Median & 4.55 & 24.20 & 29.57 & 209.39 & 2.52 & 3.24 \\
\hline Quart_1 & 3.05 & 11.58 & 21.18 & 154.69 & 1.35 & 1.05 \\
\hline Quart_3 & 5.86 & 37.16 & 43.07 & 355.65 & 5.05 & 4.36 \\
\hline Range & $2.1-11.7$ & $3.2-51.7$ & $13.5-46.8$ & $105.8-522.9$ & $0.2-8.9$ & $0.2-8.5$ \\
\hline
\end{tabular}

$\mu \mathrm{g} / \mathrm{g}$ for $\mathrm{Hg}$ and As respectively. The annual mean values $0.03,0.02 \mu \mathrm{g} / \mathrm{g}$ for $\mathrm{Hg}$ and As respectively, and these values exceeds much the control samples of $\mathrm{Hg}$ and $\mathrm{As}$ recorded in reference site No. 8.

The fluctuations of wind speed and direction from north east in summer to the North West in winter affected depositions of these metals and give variation in the annual concentrations of heavy metal tested in this area. The annual mean concentrations of dust fall recoded in the investigated area were compared with concentrations of the same metals measured in other world countries (Table 5).
A comparison of the results of this study with other data worldwide (Table 5) indicates that the rate deposition of our study are generally less than those recorded in North Sea, Jamaica, Amman and others . Cadmium in the present study exceeds the value of the same element in Bombay and W. Mediterranean. All above, the results of the present study exceed the threshold limit values (TLV) stated with the Egyptian Environment law 4/1994.

\subsection{Enrichment Coefficient}

The enrichment coefficients of the heavy metals were estimated and these are summarized in Table 6. The en- 
Table 5. Deposition rates of heavy metals $\left(\mu \mathrm{g} / \mathrm{m}^{2} \cdot \mathrm{month}^{-1}\right.$ compared with other results reported in the literature.

\begin{tabular}{ccccc}
\hline Location & $\mathrm{Zn}$ & $\mathrm{Cu}$ & $\mathrm{Pb}$ & $\mathrm{Cd}$ \\
\hline Bombay, India & 3097.0 & 785.8 & 269.9 & 3.28 \\
North Sea & 920.5 & 167.7 & 453.7 & 19.4 \\
Jamaica & 1525.5 & 332.1 & 450.4 & 184.8 \\
W. Mediterranean & 361.6 & 31.6 & 345.2 & 4.3 \\
Amman & 2474.4 & 462.8 & 349.8 & 12.5 \\
Assiut, Egypt & 235 & 29.46 & 22.33 & 4.53 \\
\hline
\end{tabular}

Table 6. Enrichment factor of heavy metals deposits at the 8 dust fall stations near the phosphate fertilizer plant.

\begin{tabular}{ccc}
\hline Element & Average & Enrichment Factor Range \\
\hline $\mathrm{As}$ & 1.9 & $0.2-4.8$ \\
$\mathrm{Cu}$ & 3.5 & $0.3-5.6$ \\
$\mathrm{~Pb}$ & 4.3 & $0.6-9.9$ \\
$\mathrm{Zn}$ & 8.7 & $3.9-19.2$ \\
$\mathrm{Cd}$ & 3.9 & $1.9-10.0$ \\
$\mathrm{Hg}$ & 2.5 & $0.2-4.6$ \\
\hline
\end{tabular}

richment coefficient was computed as the ratio of the heavy metal concentration in the settleable particulates (dust fall) to the concentration in the soil collected and analyzed at the same time [10].

The values in the table indicate high enrichment of the dust fall and follow the order $\mathrm{Zn}>\mathrm{Pb}>\mathrm{Cd}>\mathrm{Cu}>\mathrm{Hg}>$ As. The high values of enrichment coefficients suggest that these elements are anthropogenic in origin as a result of fugitive and stack emissions from phosphate fertilizer plant. Figure 4 shows enrichment factors related to dust fall stations.

\subsection{Correlation Coefficient}

The correlation coefficient (r) was calculated from element concentrations in order to predict the possibility of a common source. The (r) values are generally high recording extreme correlation of heavy metals where $\mathrm{r}=$ 0.89 for Cd-As and $r=0.88$ for $\mathrm{Zn}-\mathrm{Hg}$. Table 7 indicated that there was strong significant correlation for $\mathrm{Cd}-\mathrm{Hg}(\mathrm{r}$ $=0.54), \mathrm{Pb}-\mathrm{Cu}(\mathrm{r}=0.53), \mathrm{Pb}-\mathrm{As}(\mathrm{r}=0.52)$ and $\mathrm{Cu}-\mathrm{Hg}(\mathrm{r}=$ 0.50 ). Also $\mathrm{Hg}$ correlated $\mathrm{Zn}$ with $\mathrm{r}=0.48$ and Cd correlated $\mathrm{Zn}$ with $\mathrm{r}=0.44$. This may indicate that these metals have a common anthropogenic source; possibly fertilizer plant emissions.

\section{Conclusions}

General observations on the investigated area showed

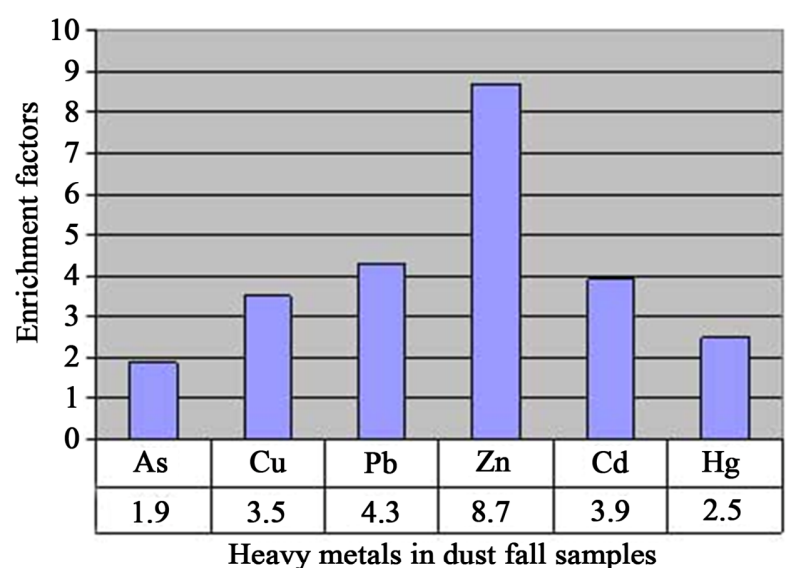

Figure 4. Enrichment factors of heavy metals in dust fall samples.

Table 7. The correlation coefficient $r$ calculated of heavy metals in dust fall samples.

\begin{tabular}{ccccccc}
\hline & $\mathrm{Cd}$ & $\mathrm{Pb}$ & $\mathrm{Cu}$ & $\mathrm{Zn}$ & $\mathrm{Hg}$ & $\mathrm{As}$ \\
\hline $\mathrm{Cd}$ & 1 & 0.18 & 0.10 & 0.44 & 0.54 & 0.89 \\
$\mathrm{~Pb}$ & & 1 & 0.53 & 0.04 & 0.10 & 0.52 \\
$\mathrm{Cu}$ & & & 1 & 0.24 & 0.50 & 0.10 \\
$\mathrm{Zn}$ & & & & 1 & 0.88 & 0.31 \\
$\mathrm{Hg}$ & & & & & 1 & 0.48 \\
$\mathrm{As}$ & & & & & & 1 \\
\hline
\end{tabular}

that vegetation environment has been adversely affected by factory emissions. Changes in plant height, canopy area, leaf area, total plant biomass, chlorophyll and necrosis may indicate the adverse affects of toxic gases such as fluoride, $\mathrm{SO}_{2}$ and allocation of dry matter at the polluted sites [17,23], reported that accumulation of heavy metals in soil hinders plants from the absorption of nutrients, affects microbial activity and causes changes of vegetation characteristics.

The study revealed that the area suffering high rates of dust fall which deteriorates plants, water, soils and make confusion for residents. Determination of heavy metals in dust fall showed that the area is heavily enriched with $\mathrm{Pb}$, $\mathrm{Zn}, \mathrm{Cu}, \mathrm{Hg}, \mathrm{Cd}$ and $\mathrm{As}$ and correlation factors indicated that these heavy metals have anthropogenic origin. Control measures may be applied to the fertilizer plant and soils may be provided with remediation technology.

\section{Acknowledgements}

The authors would like to acknowledge Dr. Atif Abo Elwafa, Dean of Sugar Research Technology Institute, SRTI for his support during this work. Also thanks to Engineer Saleh the General Manager of Environment and Safety Division in the Phosphate Fertilizer Plant for in- 
formation he provided and support during conduction of this research.

\section{REFERENCES}

[1] R. L. Solomon and W. Hartford, "Lead and Cadmium in Dusts and Soils in a Small Urban Community," Environmental Science \& Technology, Vol. 10, No. 8, 1979, pp. 773-777. http://dx.doi.org/10.1021/es60119a010

[2] S. A. Raoof and M. Al-Shahhaf, "Study of Particulate Pollutants in the Air of Riyadh by Energy Dispersive x-Ray Fluorescence Spectrometry," Atmospheric Environment, Vol. 26, No. 3, 1992, pp. 421-423.

[3] K. T. Hindy and S. A. Farag, "Composition of Suspended and Settled Particulate Matter from the Atmosphere: A Comparative Study," Environmental Pollution Series B, Chemical and Physical, Vol. 5, No. 4, 1983, pp. 247-254. http://dx.doi.org/10.1016/0143-148X(83)90020-4

[4] V. Valkovic, "Trace Elements in Coal," CCRC Press, Florida, 1983.

[5] P. K. Goel and R. K. Trivedy, "An Introduction to Air Pollution,” Technoscience Publication, Jaipur, 1998.

[6] A. Savant, "Study of Some Toxic Metals in Surface Soils in Relation to Environmental Factors," Ph.D. Thesis, Pt. Ravishankar Shukla University, Raipur, 1990.

[7] X. Querol, A. Aastuey, J. A. Puicercus, E. Mantilla, F. Plana and R. Juan, "Seasonal Evaluation of Suspended Particles around a Large Coal-Fired Power Station: Chemical Characterization," Atmospheric Environment, Vol. 32, No. 11, 1998, pp. 719-731. http://dx.doi.org/10.1016/S1352-2310(97)00340-3

[8] E. A. Ali, M. N. Nasralla and A. A. Skakour, "Spatial and Seasonal Variation of Lead in Cairo Atmosphere," Environmental Pollution Series B, Chemical and Physical, Vol. 11, No. 3, 1986, pp. 205-210. http://dx.doi.org/10.1016/0143-148X(86)90024-8

[9] M. N. Nasralla, "Lead in Jeddah Urban Dust," Environmental Pollution Series B, Chemical and Physical, Vol. 8, No. 2, 1984, pp. 133-141.

http://dx.doi.org/10.1016/0143-148X(84)90023-5

[10] Z. Kozak, J. Nieko and D. Kozak, "Precipitation of Heavy Metals in the Lȩzna-Wlodawa Lake Region," Science of the Total Environment, Vol. 133, No. 1-2, 1993, pp. 183192. http://dx.doi.org/10.1016/0048-9697(93)90120-U

[11] K. T. Hindyn, "Silicon, Aluminum, Iron, Copper and Zinc Levels in Desert Soil-Related Dust Deposits in Cairo," Atmospheric Environment, Vol. 25, No. 2, 1991, pp. 213217.

[12] R. A. Tripath, S. C. Ashawa and R. N. Khandekar, "Atmospheric Deposition of pb, cd, cu and zinc in Bombay, India," Atmospheric Environment, Vol. 27, No. 2, 1993, pp. 269-273.

[13] M. F. El-Gandour, M. S. Adel Salam, K. T. Hindy and M. M. Kamel, "Studies on Air Pollution from Construction Plants in the Helwan Industrial Area. III. Alkali, Earth
Alkali and Heavy Metal Constituents of Dust-Fall," Environmental Pollution Series B, Vol. 4, No. 4, 1982, pp. 303-313.

[14] Th. A. Taha, A. K. M. Mohamed and M. A. Gandour, "Environmental Assessment and Control of Air Emissions Related in Sugar Industry," M.Sc. Thesis, Environmental Sciences and Technology, Sugar Technology Research Institute, Assiut University, Assiut, 2009.

[15] American Society for Testing and Materials (ASTM US-EPA), "Test Method for Collection and Measurement of Dust Fall," Conshohocken, 2004.

[16] R. O. Glibert, "Statistical Pollution Monitoring," John Wiley Publication, New York, 1987.

[17] N. Dubey and S. Pervez, "Investigation of Variation on Ambient PM10 Levels within Urban-Industrial Environment," Aerosol and Air Quality Research, Vol. 8, No. 1, 2008, pp. 54-64.

[18] R. K. Sharma and S. Pervez, "A Case Study of Spatial Variation and Enrichment of Selected Elements in Ambient Particulate Matter around a Large Coal-Fired Power Station in Central India," Environmental Geochemistry and Health, Vol. 26, No. 3-4, 2004, pp. 373-381. http://dx.doi.org/10.1007/s10653-005-6369-1

[19] Y. F. Quraishi and G. S. Pandy, "Exposure of Steel Plant Related Dusts in Domestic Environments in Bhilai Residential Area," Indian Journal of Environmental Protection, Vol. 13, No. 8, 1993, pp. 580-583.

[20] J. Injuk, R. Van Grieken and G. de Leeuw, "Deposition of Atmospheric Trace Elements into the North Sea: Coasta, Ship, Platform Measurements and Model Predictions," Atmospheric Environment, Vol. 32, No. 17, 1998, pp. 3011-3025. http://dx.doi.org/10.1016/S1352-2310(97)00497-4

[21] A. Jiries, T. El-Hasan and W. Manasrah, "Qualitative Evaluation of the Mineralogical and Chemical Composition of Dry Deposition in the Central and Southern Highlands of Jordan," Chemosphere, Vol. 48, No. 9, 2002, pp. 933-938. http://dx.doi.org/10.1016/S0045-6535(02)00177-7

[22] A. M. Thabet, A. R. Rabeiy, A.-K. M. Mohamed and M. A. Ghandour, "Environmental Assessment of Heavy Metal Pollution from Phosphate Fertilizer Plants," Ph.D. Dissertation, Sugar Technology Research Institute, Assiut University, Assiut, 2013.

[23] A. D. Bhanarkar, P. S. Rao, D. G. Gajghate and P. Nema, "Inventory of $\mathrm{SO}_{2}, \mathrm{PM}$ and Toxic Metal Emissions from Industrial Sources in Greater Mumbai, India," Atmospheric Environment, Vol. 39, No. 21, 2005, pp. 38513864. http://dx.doi.org/10.1016/j.atmosenv.2005.02.052

[24] D. Narayan, M. Agrawal, J. Pandy and J. Singh, "Changes in Vegetation Characteristics Downwind of an Aluminium Factory in India," Annals of Botany, Vol. 73, No. 5, 1994, pp. 557-565.

[25] South African National Standards (SANS), "South African National Standard, Ambient Air Quality-Limits for Common Pollutants," Standards South Africa, Pretoria. 